\title{
The role of career women on children's worship education in Boyolali
}

\author{
Badrus Zaman \\ IAIN Salatiga \\ badruszaman43@yahoo.com
}

DOI: 10.18326/mudarrisa.v9i1.74-96

\begin{abstract}
The purpose of this research is to understand the role of career women in teaching worship education to their children amid their work. It is a descriptive qualitative research which is conducted in January-March 2017. Career women who have school-aged children in Jatiroto village are the subjects in this study, while their husbands, children and neighbors pose as the informants. The data are collected by interview, observation and documentation. Triangulation is used to validate the data. They are analysed with interactive models include four stages, namely data collection, data reduction, data presentation and conclusion. The results show that the roles of career women (mothers) toward children's whorship education are a) the educational backgrounds of career women consist of the degrees of Islamic High School (Madrasah Aliyah) and Islamic Boarding School (Pesantren) so that they can educate children in daily basis worship despite having dual roles, b) career women show a good attitude and become models in any aspects especially worship, c) the environment created by the career women in their family is very comfortable and suitable with the needs of children.
\end{abstract}

Keywords: roles of career women, children's worship education 


\begin{abstract}
Abstrak
Tujuan dalam penelitian ini adalah untuk mengetahui peran wanita karier dalam memberikan pendidikan ibadah pada anak-anaknya ditengah-tengah kesibukannya berkarier. Penelitian ini menggunakan penelitian deskriptif kualitatif. Penelitian dilaksanakan bulan JanuariMaret 2017. Subjek dalam penelitian ini adalah wanita karier yang memiliki anak usia sekolah dasar yang ada di dusun Jatiroto, sedangkan untuk informannya adalah suami, anak dan tetangga. Data dikumpulkan dengan wawancara, observasi dan dokumentasi. Teknik keabsahan data yang digunakan dalam penelitian ini adalah Trianggulasi. Adapun teknik analisis data dengan model interaktif meliputi empat tahap, yaitu pengumpulan data, reduksi data, penyajian data dan penarikan kesimpulan atau verifikasi. Berdasarkan hasil penelitian, menunjukkan bahwa menunjukkan bahwa Peran wanita karier (ibu) terhadap pendidikan ibadah anak adalah a) latar belakang pendidikan wanita karier (ibu) terdiri dari Lulusan Madrasah Aliyah dan Pesantren sehingga dapat mendidik anak dalam hal ibadah sehari-hari walaupun memiliki peran ganda, $b$ ) wanita karier (ibu) menunjukkan sikap yang baik dan dapat menjadi teladan dalam segala hal khususnya dalam hal ibadah sehingga bisa menjadi model bagi anak, c) lingkungan yang diciptakan wanita karier (ibu) dalam keluarga sangat nyaman dan cocok dengan kebutuhan anak.
\end{abstract}

Kata kunci: peran wanita karir, pendidikan ibadah anak

\title{
Introduction
}

Parents have an important role in determining the growth of their children. As a family component, parents have to provide education to their children. To be successful in education and work is parents' hope. Providing good education and guidance are expected to make them have a good future. Children should be continually equipped with religious knowledge and experience in order to be a young Moslem generation 
who is noble, respects time and highly discipline. Education is the most important things in life, especially when we talk about the issue of children worship education.

According to Abdul Hamid Kisyik (1995: 215), family has a fundamental position. Child development begins and enables in the family. Therefore, the portion of family time has an essential role in the process of child's potential development and personality formation.

Women have a role in teaching and showing the direction and purpose of their children in life. The women's real success is when they have succeeded in delivering their children to the gate of success. A woman in the family is recognized as the wife and mother of their children. She should give good education to their children, both religious and general education. Children should be given understanding of worship such as prayer, fasting, reciting the Qur'an and etc. as soon as possible. Religious education is important to be taught to children as a moral fortification. Thus they are not easily invaded by bad effects of globalization, such as free sex, drugs and so forth.

Muhammad Ali Al-Hasyimy (2002: 199) said that mothers' responsibility in education and personality formation of their children is greater than a father. It is because they are closer to the mother and or stay more on her side. Mothers are more familiar with their condition and developmental period of growth and puberty which is the most dangerous period for the children's pshycology and behavior.

However, in the modern era, women forgot their duties and obligations. They spend more time to work. They even forgot about their 
role as a mother to educate and nurture their children. Many parents entrust their children to nanies, Islamic nurseries, Qur'anic Education Center (TPA) etc. They do not give their own teaching to their children. They rely on the development of their children to others. Thus children will lose affection and teaching from theirmother. When it is happened, children will feel away from his parents especially from their mothers.

Almost 90\% women in Jatiroto village are career women. Various kinds of profession are performed such as teachers, midwives, entrepreneurs, laborers, traders and others. The women are married and have children. The worship of the children from the working mothers is slightly hampered because there are no more reminders. For instance, during praying Dhuhur time, they left their prayer because they are playing eagerly, and no one reminds and invites them to pray.

A dual role career woman is not an easy situation to be solved. Both roles demand equal performance. If she prioritizes her work, she can sacrifice many things for her family. Conversely, if she prioritizes the family, then she is likely to reduce her performance at work place. This is called family-work conflict. This is the dilemmatic position experienced by a career woman in her life. In fact, many career women can not proportionately balance their roles. There is often an imbalance between activities in the household and profession, so it seems to contribute very bad effect for both (Ermawati, 2016: 60).

Career women are less successful inmanaging their time between working and caring their children. If it is so, children will receive the consequences, i.e. they will be lack of education and meaningful teaching 
from their mothers. Primary school-aged is the age when children will begin to learn and follow what adults do. It is the precise time for parents to begin educating their children, especially in offering prayers.

Apparently, family problems at present and future time will be more complex because of many changes in society. In addition, the challenges faced by families are also increasingly diverse. In fact, there has been a rapid social change which caused anxiety because the old values relied upon by the community can not be applied anymore. The condition is very influential on the role changes played by husband and wife, which affects their relationship in the family (Rahmawati, 2015: 2$3)$.

A. Fauzie Nurdin (2009: 48) said that women workers in various businesses are not prohibited in Islam. Women may work in various fields of positive business both inside and outside the house, individually or in group, as long as the work is performed in an honorable, respectful nuance, and saves her religion and can avoid negative impacts of the work on herself and family.

Women may have a career as long as they do not forget their main duties and obligations to educate and takecare of their children and families. Women should manage their time between family and work, especially with their children. The children time should take into a priority.

In a study conducted by Iklima (2015: 84), providing worship education by career woman can be done by giving early religious experience to children, so that they can distinguish the good and bad 
ones. In this case, each informant always provides religious recognition since early aged for example by taking them into Islamic kindergarten, Qur'anic Education Center (TPA), and etc.

Religious education is given to the children at early age, so that they can differentiate between the good and the bad. It can be done by entering them into Islamic Kindergarten or Qur'anic Education Center (TPA). Children have not only been provided with religious education in family but also in TPA.

The establishment of Islamic religious behavior to children certainly requires support from parents, i.e. home and its surroundings. Thus, children behaviors are basically reflected in the behavior of parents. In the view of educational psychology, it is known that more than $70 \%$ of the child's behavior is mirroring or direct reflection of the parents' behaviour, in the daily life of educating their children (Fauzia, 2015: 314). Based on research conducted by Inin Fadzilah, et al (2013: 10) the factors supporting the success of child's education are communication and focus time. They are very influential to support the development of children education.

Educating children by career women can be done by taking time and communicate with children in the midst of their busy days. Focus time is very influential to provide good communication and motivation to children. So that, education will be secured and lead to better education.

As a career woman as well as a mother, women are required to share duties in educating and caring for their children. In educating children, parents can do it by establishing good communication with 
children. In any society, both develop and developing ones, the mothers' role toward children future is undeniable. Either good or bad growth of children in the future depends on the education when they formerly received in childhood.

Thus, it is natural for a mother to provide a particular time and make extra time to gather and provide education to her children. By so doing, a mother can consecutively provide comfort and affection, and her firs-hand education. Mothers' attention given to their children will influence their emotional condition.

In line with that, mothers should play important roles in children's worship education. They should pay more attentions to habituate children to worship. Their role is greater that others in children education. Thus, in any condition they should give attention to their children.

Based on the above consideration, the author is interested in studying the roles of women in the children's worship education and tends to examine the study under the title: "The Role of Career Women on Children's Worship Education in Boyolali". The purpose of this study is to understand the roles of career women in providing education of worship to their children amid his career.

\section{The role of career women}

According to E. Mulyasa (2006: 221) role is defined as a series of feelings, speeches, actions, as a unique pattern of relationships proposed by individual to other. A person can be said to perform a role if he engages in a series of feelings, speeches or actions to produce a unique 
and good relationship from one individual to another.

According to Asrifin (2007: 54) career woman is a woman who plays a double role, besides put herself as a housewife, she is also tied with other jobs. Both are located inside and outside house. Based on the understanding of the roles and career woman, it can be summarised that the role of career woman is a set of behavior performed by a woman in doing her job as a housewife and work as a professional to get an achievement inside and outside the house.

According to Abdurrahman Al-Baghdadi (2001: 88) Islam has determined that feeding the family is a duty of men, not a woman's. A woman has no obligation to earn living and meet the needs of the household. The provision of a woman's income to a man is a Shadaqah not a duty. It is a man who has the duty in fulfilling his household needs. If a woman wishes, it is allowed for a woman to work; if she is permitted by her husband or father; if she is not married, as it is mubah for her.

It is clearly stated that the expenses for family life including wife, and kids are on the hands of husbands. They are obliged to provide needs for the family based on what they can afford. A wife is not required to work to meet the needs, but the husband has this obligation.

According to M. Khalilurrahman Al-Mahfani (2015: 205) educating and taking care children is a very heavy work. It takes perseverance, patience, and carefulness to recognize the character and soul of the children, so it can easily educate them. Child is born in pure; his parents should maintain him, especially his mother who is daily interacted with. Good example of a mother is needed in educating her 
children. Selective expression and behavior in accordance with the rules of religion become a mother's reference so that it can be imitated and followed by the children.

The women activities at work will cause their families to split up and abandon their children. Women will abandon the household matters, the education and teaching of their children. The shift of women to work outside and leave their families from morning till late evening can cause some bad consequences in their family. Children need protection from his parents. If parents are left for work, they will lose their attention and protection. This can cause problems, such as play truant, drinking and so on.

The decision to be a career woman has impacts on her family, both positive and negative ones. For the positive side, the family economy will be sufficient because there are double incomes between husband and wife. In addition,the children will become more understanding and wise. Meanwhile, the negative impactis the declining of quality time between mother and children. The meetings should be utilized maximally to have communication with children. It will make relationship between mother and the children. Theywill be close even though the mother is busy. It is also suggested not to bring her works to home.

According to Khalid Al-Namadi (1997: 183) the main task of Moslem women are based on two opinions: the first is to carry out activities at home, namely to fulfill household duties and maternal tasks as well. The second tasks are limited not only in the domestic area, but 
also the outside world to work, where the time is limitless.. Fathers and mothers have different roles in children's education, andthey play on their own roles. QS. At-Tahrim 66: 6 explains:

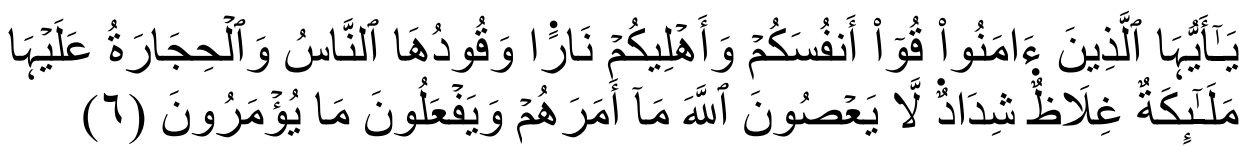
$O$ ye who believe! Save your selves and your families from a Fire whose fuel is Men and Stones, over which are (appointed) angel stern (and) severe, who flinch not (from executing) the Commands they receive from God, but do (precisely) what they are commanded. ('Ali, 2008: 708)

In Surah At-Tahrim mentioned above, it has explained that keeping the family is not only the responsibility of mothers, but also the conjunction betweenfathers and mothers. Nonetheles, the responsibility between mothers and fathers is different. Fathers have responsibility in meeting the needs of the family, while mothers are responsible with household chores and their children.

Women have an important role in giving birth of the best ummah. In short, the woman must be a good wife, a good mother and a good institution. How many good women among present time population have been born in this world due to the existence of competent mothers. The mothers educate and teach their children. In educating and providing education to children, a working mother should pay attention to them. They should pay attention to their children and communicate with them to establish a good relationship. Moreover, in educating children, a wife also should communicate and discuss it with her husband.

A Moslem mother who is really pious always loves her children 
because giving love is a very basic moral of Islam. It is no doubt that the affection given by a Muslim mother to her children is one of the biggest factors for her happiness and prosperity in this life.

\section{The problems of career women, child and family}

The following are some issues that career women, children and families often encounter. The career problems are: 1) competition and interpersonal relationships; 2) personal \& spouse life; 3) child and family issues; 4) social life and recreation time; 5) changes in patterns and lifestyles; 6) tiring condition after work; 7) getting a lot of criticism; 8) career change; 9) family or career; 10) decision to return to work; 11) the point of satisfaction; 12) the forgotten housewives' role; 13) making couples feel insecure; and 14) the presence of another ideal woman (Samsu, 2016: 8).

In terms of some career women's problems, especially related to jobs, children and families, career women are challeged with choices, which require them to decide what are their roles in career, in caring children and family.

\section{Functions of women in family}

There are 7 main functions of women in the family; First, Economic Function; as a livelihood activity, planning, improving maintenance and distributing family income to increase and maintain family welfare. Second, Protection Function is to prevent family members from situations or actions that could endanger or hamper survival, growth and 
normal development. Third, the function of education is as an activity to improve the ability, attitude and behavior of family members to support the process of creation of life and livelihood of prosperous families. In educating children, a mother must be able to be a role model for her children. Parents' behavior, especially mothers, will be imitated and then will be used as guidance in nurture. As Allah says in the Qur'an Surah Al-Furqaan 25: 74:

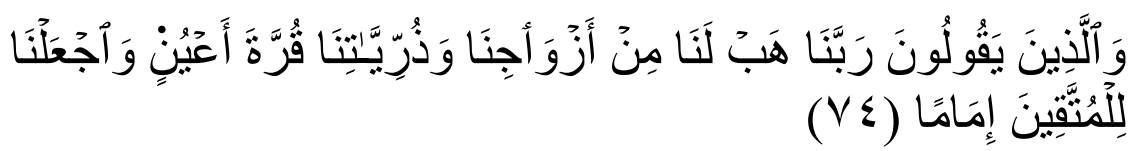

And those who pray, "Our Lord! Grant unto us wives and offspring who will be the comfort of our eyes, and give us (the grace) to lead the righteous" ('Ali, 2008: 440)

If we look at the parents' instincts as Allah says in the Qur'an, then we must realize that parents are always required to be a good example in front of their children.

Since children were born from the mothers' womb, mothers are the one who influenced personal development, behavior and morality of the child. Shaping a good child's behavior is not only by oral (bil lisan) but also by action (bil hal), by educating them through mothers' role models and behaviors. As new born babies, they will always see and observe their mother's gestures or behaviors. From what mothers have, children will refer and imitate in their life. Those child development identification process has begun since 3-5 years old.

At this age, children tend to posit mothers as the only person who can meet all their needs as well as the closest person, as a "model" for his attitude and behavior. Children will take, then have the values, 
attitudes and behavior of the mothers. At this point, it is clear that the development of children personality begins in their family, by taking the values from parents' teaching consciously and unconsciously. In this case, parents should be able to be a positive model for their children. Children will take the values, attitudes and behavior of parents. It is not only taken from what is consciously given to their children for instance through advice, but also from unconscious parents behavior.

It is a common phenomenon that many parents advise their children to do something, but they themselves do not. As the result, children will not fully take the values and norms. In order to play the role model, mothers must already have those values as their habits which are reflected in their attitude and behavior. This is important for the learning process of children in the attempt to internalize the teaching.

Fourth, socialization function is an activity to internalize and develop social or togetherness values for family members to create a harmonious atmosphere in family and community life. Fifth, religious functions is as an activity to create family relationships with God Almighty, so the family can be a melting pot of religious values, to build the faitful and noble soul of family members. Sixth, reproduction function is as a simultaneous activity to bring up offspring in a planned manner in order to create family sustainability and social welfare. Seventh, affection function is an activity to cultivate social and psychological relationships inherited by affection, tranquility and closeness (Iklima, 2015: 78).

\section{Woman's dual role}


In general, woman's dual role is defined as two or more roles that must be played by a woman at the same time. These roles are generally about the role of domestic, as housewives and general public in labors market (Rustiani, 1996: 60). Jane (1991: 45) says that people who work outside home are burdened with the dual tasks of doing household chores after they return from their jobs. Dadang Harwari in Munandar (1985: 73) says that the working women's duty is a hard job, so that they are also required to manage time for working outside the home and in the household and also demanded to be responsive with surrounding community.

The woman's dual roles can be stated as follows: First, her role as an employee; Second, as a wife to meet the needs of the husband, as the mother of the child; Third, as a housewife who holds family management; Fourth, as a member of the community who must respond to social problems. From those opinions, it can be concluded that women's participation in nation development are expected to remain faithful in their nature as women who always keep attention and perform their roles and functions in the family (Iklima, 2015: 78).

\section{Worship education}

Etymologically, according to Purwanto (2009: 19) the word education comes from the Greek "paedagogie" which is constructed from the word "pais" meaning child and "again" which means to guide. Meanwhile, according to Su'ad Ibrahim Salih (2011: 8) worship is everything that is favored by Allah and got His approval, both in the form of speech, psysical and spiritual acts. Every worship should refer to the existing 
(His) manual and have been prescribed by Allah, no more or less, no one should rely on personal opinion.

According to Hamdani Bakran Adz-Dzaky (2011: 112) worship education is the main foundation that must be submitted into the soul of children with confession, sincerity and examples of parents, family and community.

Worship education must be early introduced and gradually accustomed into children habit, so that they will grow into noble humans who obbey religious commands and avoid all prohibitions. With worship education, children are expected to not distort from the teachings of religion. They should be able to distinguish the good and the bad.

As result, religious education is an activity or an attempt to get closer to God either in the form of words or deeds in accordance with the principals and teachings of religion by keeping all Allah commandments and avoiding prohibitions. Obedience to Allah (SWT) teaches people to be patience, and being patient is the most required aspect in every activity. Therefore, every Muslim intensely needs this attitude for having tranquil and peaceful lives.

The basic education of worship is the fundamental teachings of Islam itself, namely Al-Qur'an and Al-Hadith. In the teachings of Islam, prayer is one of the pillars of Islam that must be performed by every Muslim. Offering prayers for every Muslim is anobligation (fardhu 'ain).

\section{Research Method}

This research uses descriptive qualitative method. Descriptive research 
follows the procedure of collecting data in the forms of words, images, and not the numbers (Moleong, 2004: 3). It is a study that describes a particular phenomenon or population that researchers get from individual subjects, organizational or other perspectives. It is aimed to explain the relevant aspects to the observed phenomenon and the characteristics of the phenomenon or problem.

Qualitative studies focus on processes rather than results, thus the instrument plays an important role in collecting data to solve the problems that exist in the qualitative research (Moleong, 2001: 7). Bogdad and Taylor in Moleong (2003: 4), define the Qualitative method as a research procedure that presents descriptive data of several written or oral words from persons or observers. Qualitative research is used to reveal descriptive data from information about what they do and what they experience on the research focus.

In accordance with the theme that researchers discussed, this research uses field research that is conducted directly on the field, i.e. in Jatiroto village, Manggis, Mojosongo subdistrict, Boyolali regency to obtain the necessary data. Researchers make a natural observation of a phenomenon based on the context.

\section{Research Result}

The description of children's worship education behavior in everyday life can be ilustrated in several components, such as: Child's knowledge of Islamic teachings consists of Ghairu Mahdlah and Mahdlah worship, giving charity, helping others, performing fasting and being able to 
perform prayers and recitations correctly. Purifying themselves by performing ablution are daily worships that can be observed by parents. It is important to give children understanding in establishing daily worship since childhood through habituation and parents' assistance, especially mothers.

Children show the attitude of courtesy by always do greeting, kissing parent's hands before and after school, and having tolerance to their friends. Courtesy is the result of parent's habituation, especially mothers in the family environment, so that during school and community time, children will be accustomed to say greeting, kiss an older man's hand, and have mutually tolerance to their friends.

Children's skilled in worship is tangible from the way they taking care of their own chores. They have such skills due to the teaching from their parenst. Independence is also the formation of children's behavior. Becoming indipendent individuals, children can prominently perform worship in various aspects and responsible on their own, master in memorizing daily prayers and short verses of the Qur'an. Praying and reciting the Qur'an are very good to be practiced in everyday life. Both of them will make people think brighter, feel more relaxed, more concentrated, and experience other positive values.

The roles of career women (mothers) to children's whorship education are (a) the educational background of career women consists of The degree of Islamic High School (Madrasah Aliyah) and Islamic Boarding School (Pesantren), so that they can educate children in everyday worship despite having double roles. In the morning before 
dawn, the mothers have woken up and prepared breakfast for the family. When hearing the sound of prayer calling ( $a d z a n$ ), she immediately woke up their children to perform morning prayers. Children are invited to perform the prayers collectively. It can be done in a group in the mosque or at home. In the daytime, career women do not spent a lot of time in taking care of children. During the day, they are working. They observe the children's progress and daily activities by communicating with their husbands and the children.

When they came home in the afternoon, they asked for children's condition. If they have not offered Ashr prayers, mothers need to invite children to pray together. It is intended to remind children not to forget offering prayers. When there is a schedule for Qur'anic Education Center (TPA)'s classes, they invite their children to join. Children are reminded and commanded to attend. Both, mothers and children are preparing the needs to attend TPA.

When the time of Magrib prayer has arrived, mothers and children visit the mosque together to perform Magrib prayer regularly. This setting is performed regularly and orderly, so children get accustomed with such habit. The activity was following by reciting alQur'an. This is also done regularly, so that children are structured and fluent in reciting Qur'an. When Isya' prayer time arrived, they immediately carry out Isya' prayer. The boys visit mushola to perform it. Whereas, the girls collectively perform their prayers at home with their mothers. After that, mothers help their children in studying. They accompany them and investigate what they have not understoodduring 
the learning at school. They help their children when they find a difficulty and explain it patiently.

The career women (mothers) show a good attitude and become a role model in any aspects especially in worship. Their attention and teaching will be followed and practiced by children. They tend to be closer to their mother because she has more affection and attention to the children. Communication between parents is also needed to find out their development both in academic and in other aspects. Children worship is also a priority for parents. Thus they can distinguish which are good deeds to perfom and bad deeds to avoid.

Mothers also provide good examples to children such as doing prayers in an orderly manner. If it is continually performed, children will follow and make it as habit. Parents also teach worship to children such as sholat. Since early age, children have been invited to pray together though they do not understand the meaning. It is expected that children are accustomed to perform prayers collectively and make it as their daily habit.

Parents should be more selective and meticulous in the issue of children worship education, not let children do something disgrace. Children should be given an understanding of the importance of worship as early as possible, such as worship prayer, recitation and others. With the religious teaching from their parents, children will be easy in life and can distinguish what to performand avoid.

The environment created by career women in the family is very comfortable and suitable with the needs of children. Mothers' roles in 
creating an environment to comfort and meet the needs of their children is an important thing to be count in the purposes of internalizing belief, behavioral norms based on children development, the values of life, noble attitude in community, and providing feedbacks and instructions in the problem solution. The first thing that children can get is the socialization process in the family especially for the mother. Therefore, the close relation tomothers since early-aged to adolescence even into adulthood is very influential.

A mother should have belief to follow a true religion and teach the appropriate ways of dressing, speaking, and behaving. But the most important is applying the values of life by telling children the social values in order to see and observe the situation and surrounding conditions. The mothers have such conducts in order to promote children give something useful into the community independently. However, life issues can be easy and simple, but they can be also difficult and complex. Dealing with simple issues, mothers can provide assistance, but for the difficult ones, mothers need a help form outer education. Thus, mothers send their children to schools.

\section{Conclusion}

Worship is divided into two kinds, namely Mahdlah and Ghairu Mahdlah. Ghairu Mahdlah worship is the type which the rituals are not regulated in detail by Allah and the Prophet Muhammad, for examples Endowments, Sacrifice (Qurban), Shadaqah, Aqiqah, Dhikr, Du'a and etc. Meanwhile Mahdlah Worship is a direct worship to Allah SWT 
which rituals are regulated and determined by Allah or exemplified by the Prophet Muhammad, for instances ablution, praying, fasting Ramadan, Zakah and Hajj.

Based on the discussion, the writer concludes that (1) The behavior of children's worship education in daily basis can be described in several components, i.e. a) the children's knowledge of the Islamic teachings which consists of Ghairu Mahdlah and Mahdlah worship, the ablity to perform Prayer movement correctly and to purify themselves by performing ablution; b) The children show courtesy by always greeting and respecting their friends; c) the children are skillful in worshiping, exhibited from their practice in independently taking care of their own needs, and their ablity to memorize daily prayers and verses from the Qur'an. (2) The roles of career women (mothers) to children's worship education are (a) the educational background of career women consists of the degree of Islamic High School (Madrasah Aliyah) and Islamic Boarding School (Pesantren), so that they can educate their children in everyday worship despite having double roles, (b) Career women show a good attitude and become role models in any aspects especially worshipping, (c) The environment created by the career women in their family is very comfortable and suitable with the needs of their children.

After conducting this research, the researcher proposes several recommendations, i.e. (1) the career women (i.e. mothers) should be able to manage time for their children. They should spend children's golden age because this period is very short. (2) It is needed to divide the duties between husband and wife in educating and escorting their children in 
daily worship. (3) It is required to choose the best Qur'anic Education Center (TPA) for children with parents' supervision, and establish a good relationship with the officers from TPA.

\section{References}

Adz-Dzaky, H. B. (2011). Psikoterapi dan Konseling Islam. Yogyakarta: Fajar Pustaka Baru.

Al-Baghdadi, A. (2001). Emansipasi Adakah dalam Islam. Translated by Muhammad Ustman Hatim. Jakarta: Gema Insani Press.

Ali Al-Hasyimy, M. (2002). Jati Diri Wanita Muslimah. Translated by M. Abdul Ghoffar E.M. Jakarta: Pustaka Al-Kautsar.

Ali, A. Y. (2008). The Holy Qur'an, Original Arabic Text with English Translation \& Selected Commentaries. Kuala Lumpur: Saba Islamic Media.

Al-Mahfani, M. K. (2015). Wanita Idaman Surga. Jakarta: PT. Wahyu Media.

Al-Namadi, K. (1997). Risalah Buat Wanita Muslimah. Translated by Ummu Udhma Azmi. Solo: CV. Pustaka Mantiq.

An-Nakhrawie, A. (2007). Citra Wanita Shalihah. Surabaya: Ikhtiar.

Departemen Agama RI. (2010). Al-Qur'an dan Terjemahnya. Semarang: CV. Alwaah.

Ermawati, S. (2016). Peran Ganda Wanita Karier (Konflik Peran ganda Wanita Karier ditinjau dalam Perspektif Islam). eJournal Edutama. Vol 2 No 2: 60.

Fadzilah, I., et. al. (2013). Peran Wanita Karir dalam Mendukung Keberhasilan Pendidikan Anak Di Kota Pontianak. Pontianak: Universitas Tanjungpura.

Fauzia, S. N. (2015). Perilaku Keagamaan Islam pada Anak Usia Dini. eJournal Pendidikan Usia Dini. Vol 9 No 2: 314.

Iklima. (2015). Peran Wanita Karir dalam Melaksanakan Fungsi 
Keluarga (Studi Kasus PNS Wanita yang Telah Berkeluarga di Balai Kota Bagian Humas dan Protokol Samarinda).eJournal Ilmu Sosiatri, 2 (3): 77-89.

Kisyik, A. H. (1995). Bimbingan Islam untuk Mencapai Sakinah. Bandung: Al-Bayan.

Moleong, L. J. (2001). Metodologi Penelitian Kualitatif. Bandung : Remaja Rosdakarya.

Moleong, L. J. (2004). Metodologi Penelitian Kualitatif. Bandung: Remaja Rosdakarya.

Moleong, L. J. (2010). Metodologi Penelitian Kualitatif. Bandung: Remaja Rosdakarya.

Mulyasa, E. (2006). Menjadi Kepala Sekolah Protensial. Bandung: Remaja Rosda Karya.

Nurdin, A. F. (2009). Wanita Islam dan Transformasi Sosial Keagamaan.Purwanto. 2009. Evaluasi Hasil Belajar. Yogyakarta: Pustaka Pelajar.Yogyakarta: Gama Media.

Rahmawaty, A. (2015). Harmoni dalam Keluarga Perempuan Karir: Upaya mewujudkan Kesetaraan dan Keadilan Jender dalam Keluarga. eJournal Palastren, Vol 8 No 1:2-3.

Samsu. (2016). Persoalan Wanita Karir dan Anak dalam Keluarga Pegawai Negeri Sipil di Provinsi Jambi.eJournal Harakat AnNisa: Jurnal Studi Gender dan Anak. Vol 1 1. No 1: 8.

Shalih, S. I. (2011). Fiqh Ibadah Wanita. Translated by Nadirsah Hawari. Jakarta: Sinar Grafika Offset.

Syarifudin, A. (2010). Garis-Garis Besar Fiqh. Jakarta: Prenada Media Group. 